\title{
LEPTOTHORAX PARAXENUS N. SP., A WORKERLESS SOCIAL PARASITE FROM NORTH AMERICA (HYMENOPTERA: FORMICIDAE)
}

\author{
By J. Heinze ${ }^{1}$ AND T.M. Alloway ${ }^{2}$
}

\section{INTRODUCTION}

Of the approximately 9000 species of ants, some 200 are dependant on the help of workers from other species during a part or the whole of their life cycles (Buschinger 1986, Hölldobler \& Wilson 1990). About 15 per cent of these social parasites belong to the myrmicine tribe Leptothoracini with its major genus Leptothorax and about half a dozen closely related genera. We here describe a new, apparently workerless parasitic ant from Ontario and Québec, Canada.

\section{Leptothorax paraxenus, $\mathrm{n} . \mathrm{sp}$.}

Fig. 1

Holotype female: an intermorphic queen from Milton, Ont.

Total length appr. $3.4 \mathrm{~mm}$, head length (excluding mandibles) 0.82 , head width (behind eyes) 0.70 , scape length 0.52 , maximum eye diameter 0.18 , thorax length (Weber's) 1.08 , width of pronotum 0.53 , length of petiole in lateral view 0.35 , height of petiole at node in lateral view 0.43 , maximum width of petiole 0.28 , length of postpetiole 0.23 , height of postpetiole 0.33 , maximum width of postpetiole 0.43 , length of hind femur 0.63 , length of hind tibia 0.51 .

The habitus of the holotype female (Fig. 1) is similar to those of intermorphic queens of other leptothoracine ants, such as $L$. sphagnicolus (Francoeur 1986), L. sp.A (Heinze and Buschinger 1987), and Formicoxenus (Francoeur et al. 1985). The thorax is permanently wingless but otherwise only slightly different from that of winged females. One pair of darkly pigmented vestigial wing attachment sites is present in the site of the forewings.

\footnotetext{
${ }^{1}$ Zoologisches Institut (II) der Universität, D8700 Würzburg, F.R.G.

${ }^{2}$ Erindale College, University of Toronto, Mississauga, Ontario L5L 1C6, Canada

*Manuscript received 1 July 1991.
} 
Promesonotal, transscutal, mesometanotal sutures, and parapteron are clearly visible. Head as in fig. 1. Antennae 11-segmented with a 3-jointed apical club. The scape is distinctly stronger than that of other Leptothorax, as are the legs. Mandibles with five or six teeth; maxillary palps 5-segmented, labial palps 3-segmented. Anterior border of the clypeus is visibly notched. Three ocelli present. Propodeal spines of moderate size, acute. Epinotal spine index (Buschinger 1966) appr. 1.5. Petiole in dorsal view with distinctly convex sides. In profile petiole lacking an anterior peduncle, node prominent, with a flat apex. Anterior face concave, posterior face slightly convex. Subpetiolar process large, in lateral view forming a convex ridge. Lateral edges of petiole at base of node terminate anteriorly in two small teeth. Petiolar node apex viewed from rear slightly concave. Postpetiole in dorsal view markedly trapezoidal; anterior margin 1.6 times broader than maximum diameter of petiole, 1.5 times broader than posterior margin of postpetiole. In profile, postpetiole with evenly rounded dorsal surface and well-developed anteroventral tooth. Head, thorax, petiole, and postpetiole weakly rugulose, gaster smooth and shining. Body sparsely covered with short, stiff erect and suberect hairs. Legs with sparse, appressed, short hairs and few scattered erect hairs. Antennal scape with moderately abundant appressed hairs, funiculus with dense suberect hairs. Coloration a light yellowish brown with antennae, head, and gaster distinctly darker.

Paratypes: two intermorphic females from Milton, Ont.

The paratype intermorphs differ little from the holotype. The thoracic sclerites are more widely fused. Promesonotal and mesometanotal sutures are present, but the transscutal suture and the parapteron are only slightly visible; they are completely reduced in other specimens.

Paratype female: gynomorphic female from Milton, Ont. Fig. 2

Total length appr. $3.25 \mathrm{~mm}$, head length 0.82 , head width 0.70 , scape length 0.50 , maximum eye diameter 0.19 , thorax length 1.13 , thorax width 0.55 , length of petiole 0.32 , height of petiole 0.47 , width of petiole 0.28 , length of postpetiole 0.27 , height of postpetiole 0.35 , width of postpetiole 0.45 , length of hind femur 0.63 , length of hind tibia 0.52 . 

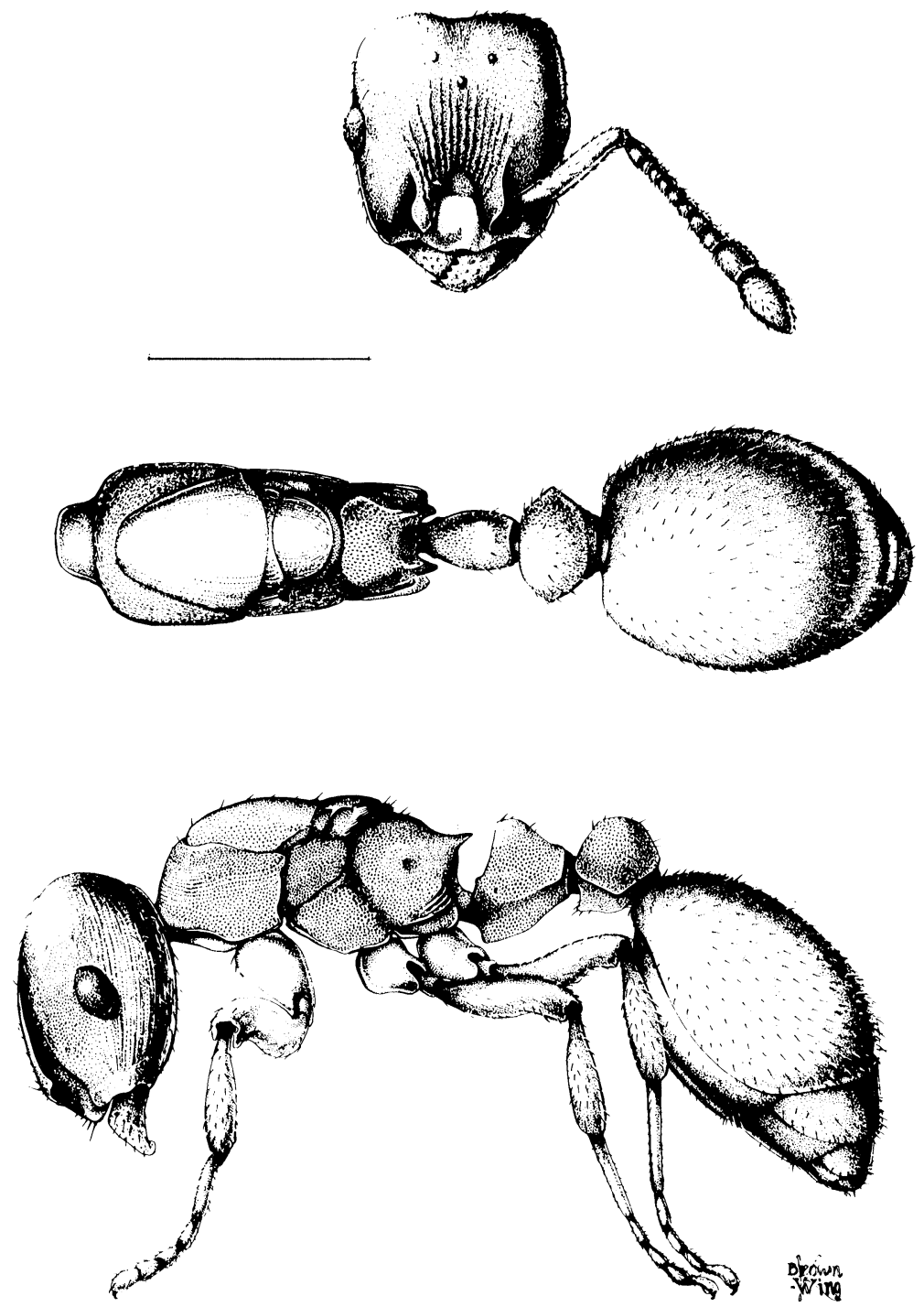

Figure 1. Habitus of the intermorphic holotype female of Leptothorax paraxenus n.sp. from Milton, Ontario. From top to bottom: head in frontal view; thorax, petiole, postpetiole, and gaster in dorsal view; whole body profile (scale: bar $=1 \mathrm{~mm}$ ). 
Similar to holotype but with more strongly impressed thoracic sutures (Fig. 2). Newly eclosing gynomorphic females have two pairs of well developed wings. Paratype: male from Milton, Ont. Figs. 3 and 4.

Total length appr. $3.8 \mathrm{~mm}$, head length 0.62 , head width 0.60 , scape length 0.22 , maximum eye diameter 0.23 , thorax length 1.25 , thorax width 0.60 , length of petiole 0.37 , height of petiole 0.31 , width of petiole 0.24 , length of postpetiole 0.25 , height of postpetiole 0.27 , width of postpetiole 0.30 , length of forewing 3.13 , length of hindwing 2.25 , length of hind femur 0.63 , length of hind tibia 0.55 .

The male is similar in habitus to males of other Leptothorax s. str. (Fig. 3). Antennae 12-jointed, thorax with Mayrian furrows; propodeum with small, but distinct teeth. Petiole lacking anterior peduncle, ventral side forms a slightly convex ridge. Postpetiole with a distinct ventral tooth. Head, thorax, and petiole coarse, dorsal part of the postpetiole and gaster largely smooth and shining. Body covered with tapering, curved, suberect hairs. Coloration black. Wing venation as in fig. 4 .

\section{Type locality:}

Milton, Halton County, Ontario. The colonies were collected by J.H. on May 18, 1990 in a dense deciduous forest (mainly oaks, beeches, a few white pines and hickory), on Britannia Road (County Road No. 6), 500m west of the intersection with King's Highway 25. Colonies nested in hollow sticks and also in rotting branches.

\section{Derivatio nominis:}

The species name paraxenus refers to the parasitic life (ó xenos, Greek "guest") of the new species. "paraxenos" means "peculiar" in modern Greek.

\section{Disposition of types:}

Holotype female, one paratype intermorphic female, the gynomorphic female, and the paratype male are deposited in the Museum of Comparative Zoology, Harvard University, Cambridge, Mass. One intermorphic female has been deposited in the British Museum, London. 


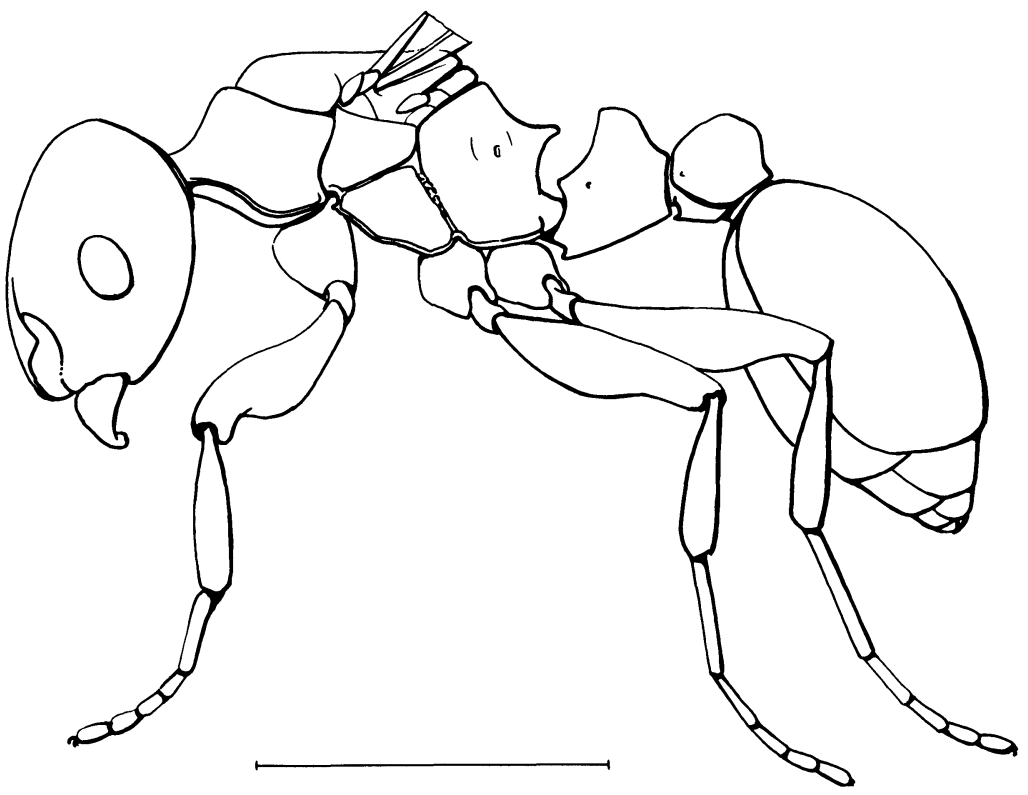

Figure 2. Habitus of the gynomorphic paratype female of Leptothorax paraxenus n.sp. (scale: bar $=1 \mathrm{~mm}$ ).

\section{Diagnosis:}

Both gynomorphic and intermorphic queens of $L$. paraxenus are easily distinguished from queens of the black host species, Leptothorax sp.B, by their light coloration. They differ from most of the similarly brownish Leptothorax (s.str.) - the nearctic L. retractus Francoeur, the holarctic L. acervorum (Fabricius) and the palaearctic species L. muscorum (Nylander), L. gredleri Mayr, and L. scamni Ruzsky - in the strongly developed ventral ridge of the petiole and the conspicuous postpetiolar spine. The workerless parasite Leptothorax faberi Buschinger from the Canadian Rocky Mountains shares some morphological characters with $L$. paraxenus, such as the light brown color, the feebly notched clypeus, and the shape of the subpetiolar spine, but the "inflated" petiole of $L$. paraxenus easily distinguishes between the two species. Females of the yet undescribed nearctic Leptothorax sp.A (Heinze and Buschinger 1987) are also rather similar to L. paraxenus queens on a first glance. Intermorphic queens of sp.A are common, 

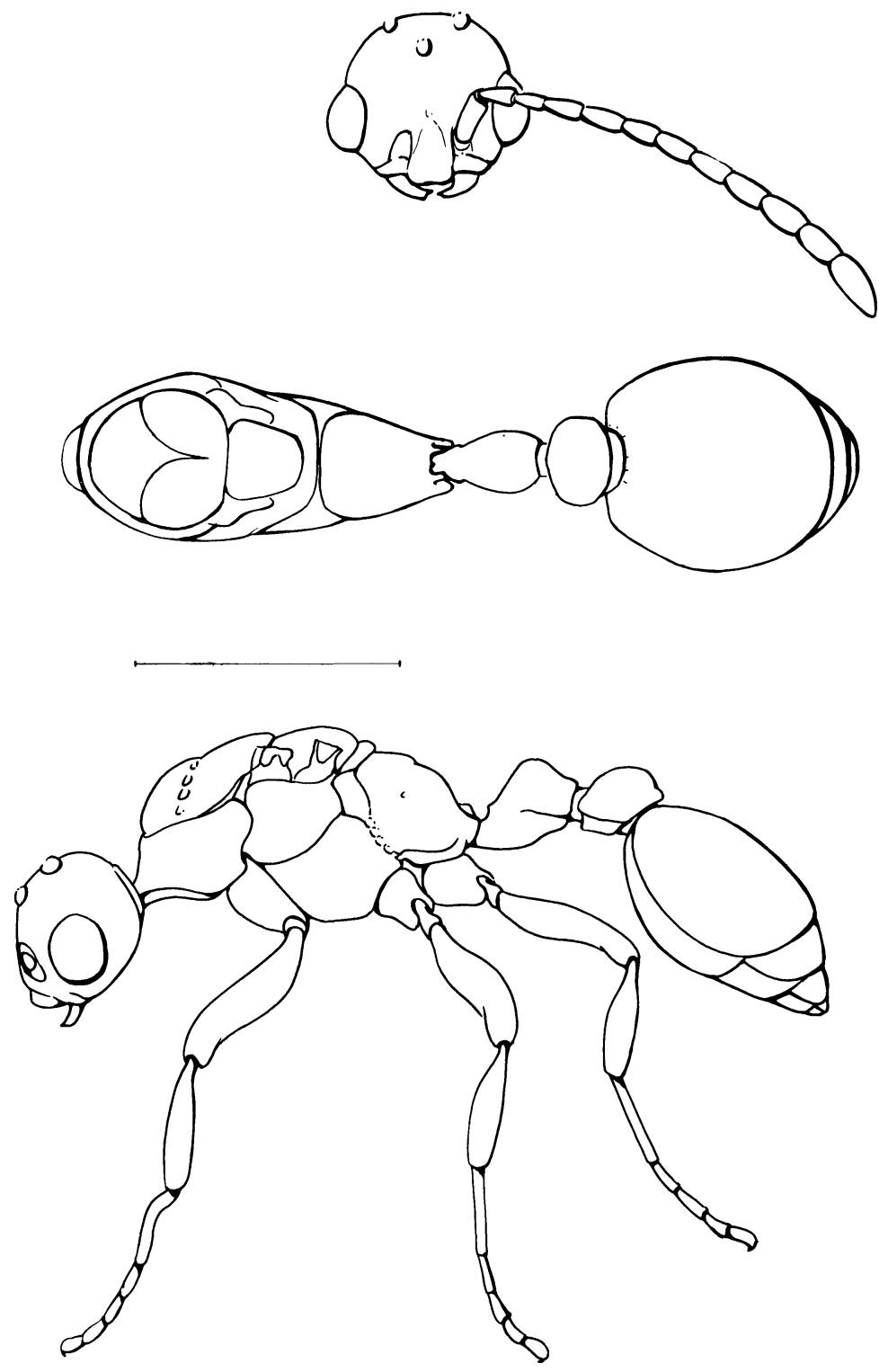

Figure 3. Habitus of the paratype male of Leptothorax paraxenus n.sp. From top to bottom: head in frontal view; thorax, petiole, postpetiole, and gaster in dorsal view; whole body profile (scale: bar $=1 \mathrm{~mm}$ ). 


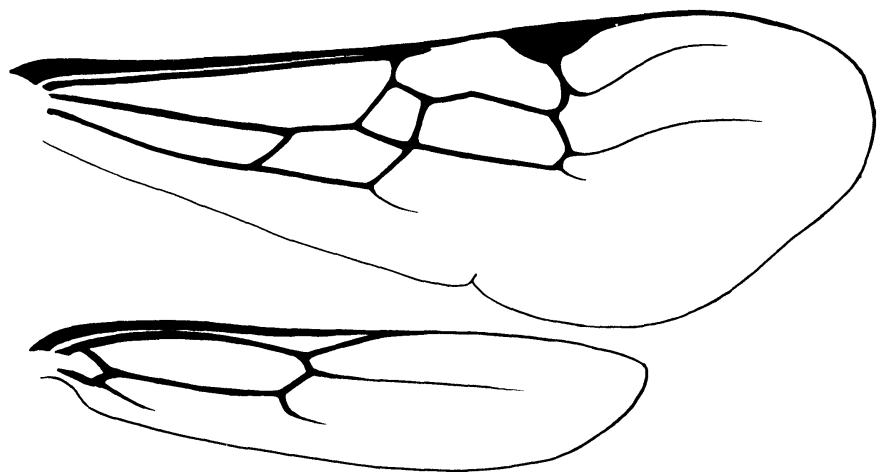

Figure 4. Venation of the right forewing (top) and hindwing (bottom) of a Leptothorax paraxenus male (scale: $\mathrm{bar}=1 \mathrm{~cm})$.

especially along the shores of St. Lawrence River, and in many specimens a distinct postpetiolar spine is present. However, in $L$. sp.A the sides of the petiole are not convex in dorsal view and the subpetiolar process is very different in shape, never forming a concave ridge, but instead a rounded, often drop-shaped tooth. The propodeal spines of $L$. sp.A are long and slender, with an epinotal spine index of approximately 1.8 to 1.9 . In two laboratory nests of $L$. sp.A, both descending from one single stock colony from Rivière Romaine, Co. de Saguenay, Québec, several workers and intermorphic females eclosed that had a markedly "inflated" petiole, similar to that of $L$. paraxenus (Heinze, unpubl.). However, these individuals differ from $L$. paraxenus females in all other characters mentioned above. $L$. sp.A has not been found near Milton and generally seems to be absent from deciduous forests. However, colonies were collected on rocky outcrops near Bic, only a couple of kilometers away from a population of L. paraxenus, though in a different habitat.

The color of $L$. paraxenus is reminiscent of that of aberrant yellow Leptothorax ants which are infested with cysticercoids of dilepidid tapeworms (Plateaux 1972, Buschinger 1973, 1989, Stuart and Alloway 1988). These ants often exhibit some morphological peculiarities of social parasites, e.g. the broad postpetiole, and might therefore be mistaken for parasite females. The presence of 
cysticercoids can easily be confirmed through dissection: two individuals of $L$. paraxenus from Bic were dissected by A. Buschinger and one of the authors (J.H.), and no cysticercoids were found.

\section{Discussion}

The subgenus Leptothorax (s.str.) M. R. Smith (= Mychothorax Ruzsky) comprises about a dozen or more species, of which most North American taxa still have to be reliably defined. The majority of non-parasitic nearctic Leptothorax (s.str.) had been synonymized with the palaearctic L. muscorum (Nylander) by Brown (1955), and as yet only L. crassipilis Wheeler, L. retractus Francoeur and $L$. sphagnicolus Francoeur are formally described. Several taxa from eastern North America and the Canadian Rocky Mountains, among them the host species of L. paraxenus, have been characterized by karyotypes (Loiselle et al. 1990) and isozyme patterns (Heinze 1989a). The host of L. paraxenus, referred to as $L$. sp.B in previous papers (e.g., Heinze 1989a, b), is probably identical to what was originally described as $L$. canadensis by Provancher in 1883 .

L. paraxenus closely resembles the non-parasitic species of Leptothorax (s.str.), as do many other workerless social parasites, e.g., the North American taxa Leptothorax faberi Buschinger, and $L$. wilsoni Heinze. Some authors have recently treated the palaearctic parasites L. kutteri Buschinger and L. goesswaldi Kutter as belonging to an exclusively parasitic genus, Doronomyrmex (Buschinger and Klump 1988, Hölldobler and Wilson 1990, Douwes 1990), but it has also been argued that it is not reasonable to maintain social parasites in genera different from those of their hosts (BaroniUrbani 1990). Until a comprehensive, generic-level revision of the tribe Leptothoracini has not been completed, the current placement of the nearctic social parasites (including L. paraxenus) in Leptothorax remains tentative. Within Leptothorax enzyme studies indicate that $L$. paraxenus is more closely related to a cluster of small brown Leptothorax (s.str.) (L. muscorum, L. gredleri, L. sp.A) than to its large black host (Heinze, 1991).

During the last 15 years, 12 colonies of $L$. paraxenus have been collected in three different sites in Canada. Apart from the type locality, Milton near Toronto, Ontario, nests were found near the mouth of Rivière de Sud-Ouest in Bic, Comté de Rimouski, 
Québec, and in a now destroyed site in Mississauga, Peel Co., Ont. The ants nested in rotting sticks in a deciduous forest with oaks, maples, beeches, and some white pines (Milton) or in a rather dense forest of spruces, pines, mountain-ash and other deciduous trees (Bic). In Mississauga, nests were collected from old white pine stumps under a row of planted hawthorn trees, piled one on top of another probably when the area had been originally cleared for cultivation. The host species, $L$. sp.B, is rather abundant in these localities; other sympatric leptothoracines are the slavemaker Harpagoxenus canadensis, also found with $L$. sp.B, $L$. (Myrafant) ambiguus and L. (Myrafant) longispinosus, and, in their nests, the slave-maker Protomagnathus americanus.

In Milton and Bic, about $20 \%$ of the nests of $L$. sp. B we collected were parasitized by $L$. paraxenus. No colonies of $L$. paraxenus have as yet been found in other extensively studied populations of the host species, such as the extended coniferous forests near Rouyn-Noranda (Co. de Temiscamingue, Québec) and Tadoussac (Co. de Saguenay, Québec), the York Regional Forest near Ballantrae (York Co., Ontario) only $70 \mathrm{~km}$ away from the type locality, and Mt. Monadnock in southernmost New Hampshire (Cheshire Co.).

All L. paraxenus colonies contained numerous (up to 150) workers, all belonging to the black host species. In the laboratory, the colonies produced males, gynomorphic and intermorphic females of $L$. paraxenus and males, females, and workers of the host. We therefore assume that L. paraxenus is a workerless parasite. Queens of L. paraxenus are exceptional among workerless leptothoracines in being similar in size to the host queens. The queens of Epimyrma adlerzi, E. corsica, Chalepoxenus brunneus, Doronomyrmex pacis, Leptothorax kutteri, L. goesswaldi, L. faberi, and L. wilsoni are all significantly smaller than host queens and in most cases also than host workers (Douwes 1990). Only the queens of Doronomyrmex pocahontas are as large as those of their host (Buschinger 1979), but new data suggest that this species is not a workerless parasite (Heinze and Buschinger, unpubl. res.).

In five of the $12 \mathrm{~L}$. paraxenus colonies, host females were present, but these have not been dissected. It is therefore not known whether egg-laying host queens are tolerated in the nests of the new parasite species, and thus whether L. paraxenus is a true 
inquiline, such as L. kutteri, or a murder parasite, such as $L$ goesswaldi, which assassinates them. None of the remaining seven colonies of $L$. paraxenus contained $L$. sp.B queens, but winged host queens were reared from the brood in the laboratory. One nest of $L$. paraxenus from Mississauga contained three parasite females, one gynomorph and two intermorphs. These again have not been dissected and it is possible that they were young or uninseminated females. All other colonies contained only one single female. With the exception of $D$. kutteri, all known workerless leptothoracine parasites most probably are obligatorily monogynous. In evolutionary terms it seems to be adaptive for a female not to tolerate additional parasites once the host queen has been killed or expelled. Host workers then are limited in supply and it should be in the interest of the parasite queen to spare them exclusively for her own offspring.

First observations suggest that mating takes place in or near the maternal colony. About ten days after their eclosion, males and a few days later, females started to leave the laboratory nest and to move around in the arena. Males became highly active in the late morning and tried to mount females both within and outside of the nest. Females did not show the sexual calling behavior known from other leptothoracines (e.g., Buschinger, 1968) and most copulation attempts failed, but dissection of young females showed that some males had been successful. Only in two cases complete matings were observed, during which the male inserted its copulatory organs into the female's genital opening. During the copulation, which lasted for 20 to 30 seconds, the female's sting was protruded as in other leptothoracine ants. After mating we placed the females into queenless nests of the host species, where they were accepted without any visible aggression, and started to lay eggs within three weeks. In further experiments, the behavior of young parasites will be studied in queenright host colonies.

\section{SUMMARY}

Male, gynomorphic and intermorphic female of the myrmicine ant Leptothorax paraxenus are described. The new species apparently is a workerless social parasite, which lives in nests of Leptoihorax sp. B of the L. "muscorum" (L. canadensis) complex. Colonies were found in Milton and Mississauga, Ontario, and in 
Bic, Québec. L. paraxenus differs from other Leptothorax in its "inflated" petiole and a convex subpetiolar process.

\section{ACKNOWLEDGEMENTS}

We thank Robin J. Stuart, now at University of California in Davis, Axy Leighl, Erindale College, Mississauga, and Sabine Kauffmann, Schaafheim, F.R.G., for collecting some of the colonies. A. Buschinger, Darmstadt, and B. Hölldobler, Würzburg, made helpful comments on the manuscript. Kathy Brown-Wing, Museum of Comparative Zoology, Cambridge, Mass. made drawings of the type specimens. The study was supported in part by a DFG grant to Bert Hölldobler, Würzburg, F.R.G.

\section{REFERENCES}

BARONI-URBANI, C.

1990. Phylogeny and behavioral evolution in ants, with a discussion of the role of behaviour in evolutionary processes. Eth. Ecol. Evol. 1: $137-168$.

BROWN, W.L.

1955. The ant Leptothorax muscorum (Nylander) in North America. Ent. News 66: 43-50.

Buschinger, A.

1966. Leptothorax (Mychothorax) muscorum Nyl. und L. (M.) gredleri Mayr zwei gute Arten. Ins. Soc. 13: 165-172.

1968. "Locksterzeln" begattungsbereiter ergatoider Weibchen von Harpagoxenus sublaevis NYL. (Hymenoptera, Formicidae). Experientia 24: 297.

1973. Ameisen des Tribus Leptothoracini (Hym., Formicidae) als Zwischenwirte von Cestoden. Zool. Anz. 191: 369-380.

1979 Doronomyrmex pocahontas n.sp., a parasitic ant from Alberta, Canada (Hym., Formicidae). Ins. Soc. 26: 216-222.

1986. Evolution of social parasitism in ants. TREE 1: 155-160.

1989. Bandwurmfinnen in Ameisen. Die Waldameise 2: 45-48.

Buschinger, A. AND KLUMP, B.

1988. Novel strategy of host-colony exploitation in a permanently parasitic ant, Doronomyrmex goesswaldi. Naturwissenschaften 75: 577-578.

DOUWES, P.

1990. Morphology of the parasitic myrmicine ant. In: Veeresh, G.K., Mallik B., and Viraktamath, C.A. (eds.) Social insects and the environment. Oxford \& IBH, New Delhi., 147-148.

Francoeur, A.

1986. Deux nouvelles fourmis néarctiques, Leptothorax retractus et Leptothorax sphagnicolus (Formicidae, Hymenoptera). Can. Ent. 118: 1151-1164.

Francoeur, A., Loiselle R., And Buschinger A.

(1985) Biosystématique de la tribu Leptothoracini (Formicidae, Hymenoptera). 
1. Le genre Formicoxenus dans la région holarctique. Naturaliste can. (Rev. Ecol. Syst.) 112: 343-403.

HEINZE, J.

1981a. A biochemical approach toward the systematics of the Leptothorax "muscorum" group in North America (Hymenoptera, Formicidae). Biochem. Syst. Ecol. 17: 595-601.

1989b.Leptothorax wilsoni n.sp., a new parasitic ant from eastern North America (Hymenoptera, Formicidae). Psyche 96: 49-61.

1991. Biochemical studies on the relationship between socially parasitic ants and their hosts. Biochem. Syst. Ecol. 19: 195-206.

Heinze, J. AND BusChINGER, A.

1987. Queen-polymorphism in a non-parasitic Leptothorax species (Hymenoptera, Formicidae). Ins. Soc. 34: 28-43.

HÖLLDOBLER, B. AND WILSON, E.O.

1990. The Ants. Harvard University Press, 732 pp.

Loiselle, R., Francoeur, A., Fischer, K., And Buschinger A.

1990. Variations and taxonomic significance of the chromosome numbers in the nearctic species of the genus Leptothorax (s.s.) (Formicidae: Hymenoptera). Caryologia 43: 321-334.

Plateaux, L.

1972. Sur les modifications produits chez une fourmi par la présence d'un parasite cestode. Ann. Sci. Nat. 12 $2^{\text {ième }}$ sér. 14: 203-220.

Provancher, L.

1883. Formicides. - Petite faune entomologique du Canada. Volume II, 584-603.

Stuart, R.J. AND Alloway T.M.

1988. Aberrant yellow ants, North American Leptothorax species as intermediate hosts of cestodes. In: Trager, J.C. (ed.) Advances in Myrmecology. E.J. Brill, Leiden, New York, 537-545. 

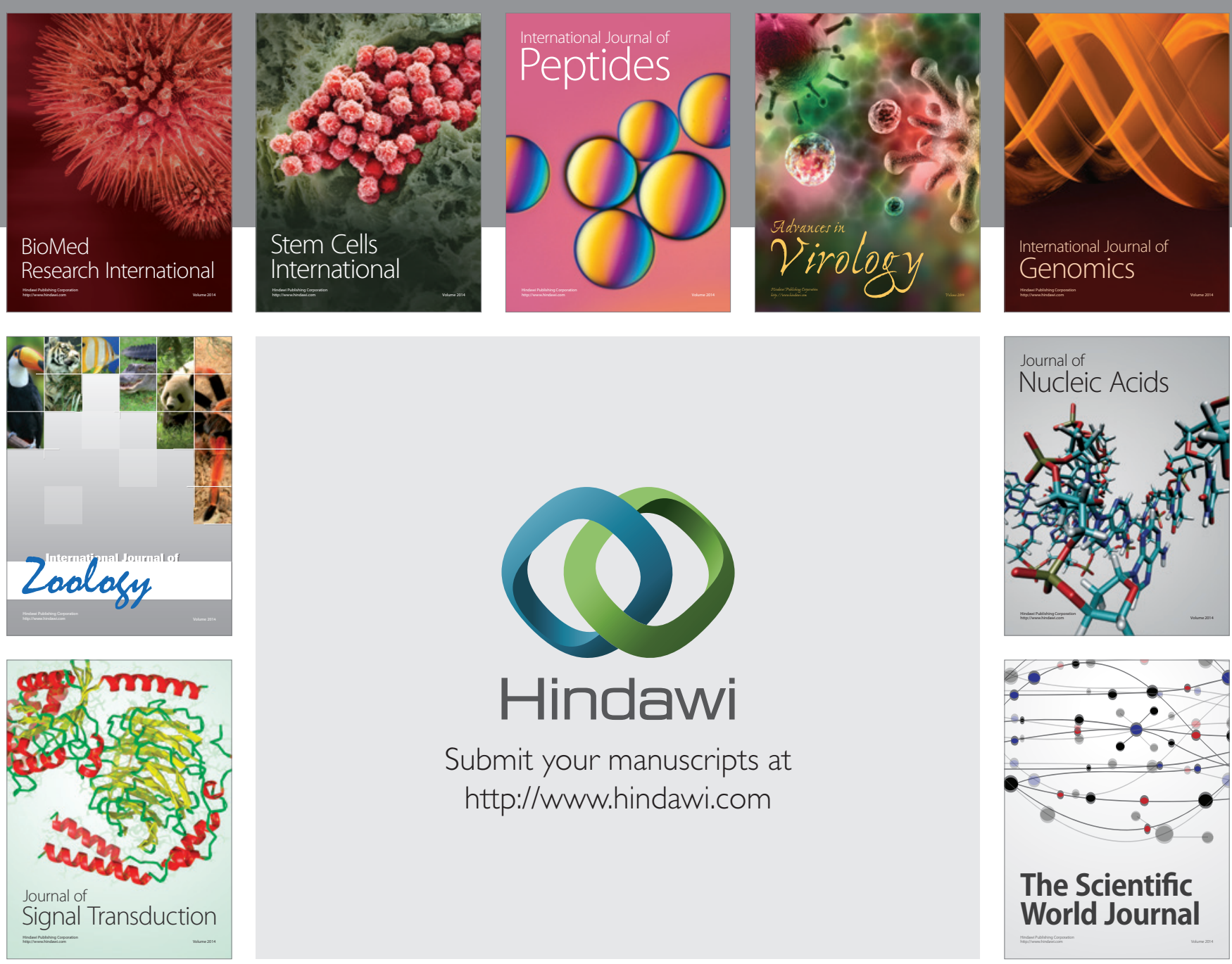

Submit your manuscripts at

http://www.hindawi.com
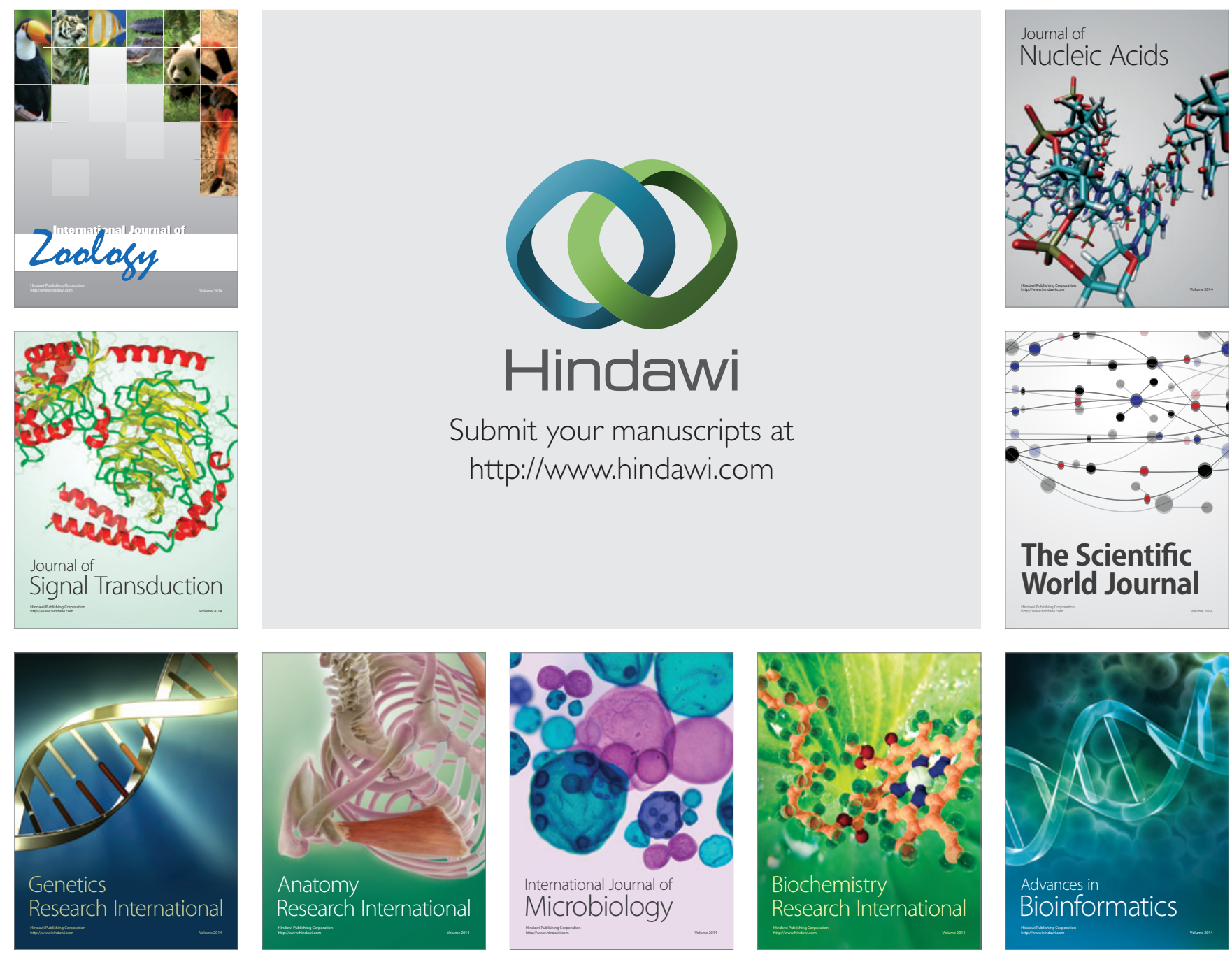

The Scientific World Journal
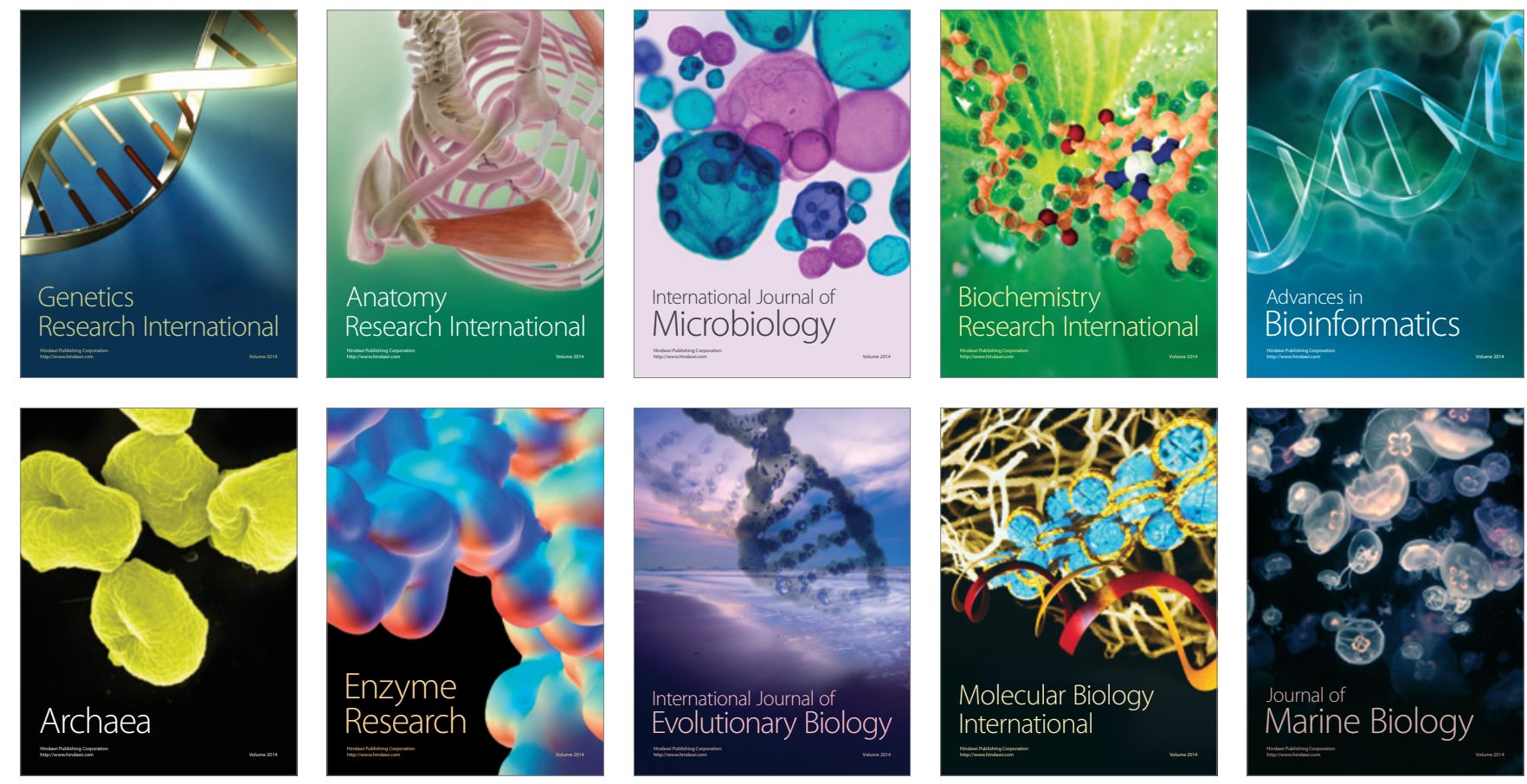